\title{
The effect of microteaching lesson study on the beliefs of EFL student teachers
}

\author{
Fitri Budi Suryani*, Rismiyanto \\ English Education Department, Universitas Muria Kudus, Indonesia
}

*Corresponding Author

Email: rismiyanto@umk.ac.id
Received:
Revised:
19 July 2020
Accepted:
Published:
4 May 2020
27 February 2021
28 February 2021

\begin{abstract}
Microteaching lesson study, that is a variation of lesson study applied by student teachers in microteaching course, provides the environment for EFL student teachers to collaborate, engage, and reflect on their ideas, beliefs, and teaching experiences. Such condition is a fertile ground that enables the student teachers' beliefs of language learning to change. Recent studies show that some education programs have changed the beliefs of student teachers. However, no studies have discussed the changes of beliefs of English as a Foreign Language (EFL) student teachers experienced in microteaching lesson study. This present study aims to investigate the effect of microteaching lesson study on EFL student teachers' beliefs. The data were collected using a questionnaire on Beliefs About Language Learning Inventory (BALLI) adapted from Horwitz administered before and after microteaching lesson study. The participants were the EFL student teachers enrolling in a microteaching lesson study class at Universitas Muria Kudus. The study reveals that the beliefs of EFL student teachers did not change significantly after they experienced microteaching lesson study. Time seems to be one of the most influential factors in hindering the changes of beliefs of the EFL student teachers. Therefore, this study suggests that EFL student teachers be given more time to practise teaching in the microteaching course.
\end{abstract}

Keywords: EFL student teachers; language learning beliefs; microteaching lesson study

\section{INTRODUCTION}

Microteaching lesson study is the practice of microteaching that combines microteaching and lesson study. Therefore, it takes the elements from both microteaching and lesson study. The elements from microteaching include the reduced length of teaching time, the reduced number of students, and the use of video to capture the teaching practice. Meanwhile, the lesson study elements are the collaboration of student teachers in conducting microteaching (a group of three or four student teachers) and the cycle of lesson study, i.e. lesson planning, implementing, and reflecting.

Microteaching lesson study provides circumstances that enable student teachers to participate and interact in teaching learning context. Using Johnson's terms (2009), microteaching lesson study gives learning 
Suryani, F.B., \& Rismiyanto (2021). The effect of microteaching lesson study on the beliefs of EFL student teachers. EduLite: Journal of English Education, Literature, and Culture, 6 (1), 1-9. http://dx.doi.org/10.30659/e.6.1.1-9

opportunities in which individuals can participate in activities that provide them with direct experiences. Therefore, it empowers student teachers because it encourages reflection and collaboration as well as connect theory to practice (Fernandez, 2010). Furthermore, Zhou and Xu (2017) report that microteaching lesson study give opportunities for student teachers to reflect on their teaching practice, give feedback, and learn collaboratively.

The collaboration and cycle of lesson study implemented in microteaching lesson study also contribute the condition that engages student teachers in sharing, discussing, and reflecting ideas and experiences critically and constructively. As a result, this might add, reduce, and or change their views and beliefs about teaching and learning realized in their choices of technique, method, media of teaching, and instructional activities in the classroom. Borg et al. (2014) state that the courses taken by student teachers likely impact them when they have opportunities to become aware of their prior beliefs about teaching and learning and to reflect on these. Furthermore, Prawat (1992) mentions that teaching experience is one of factors that mostly form teachers' beliefs. Peacock (2001), Mattheoudakis (2007), Borg (2011), Altan (2012), and Ozmen (2012) indicate that education programs could change the beliefs of preservice teachers about learning and teaching. Therefore, microteaching lesson study with its strengths like collaboration, reflection, and engagement might present a fertile field for student teachers to have their beliefs changed.

Apart from the resistance or changes of beliefs, teachers' beliefs themselves play an important role in teaching learning process. Abad (2013) mentions that beliefs as internal factors shape the classroom roles and relationships. Ernest as cited in Khader (2012) notes that teachers' beliefs are considered as the strongest factors through which we can predict the teaching behaviour as those beliefs are converted into a practical reality. In addition, some studies (Borg, 2011; Borg \& Al-Busaidi, 2012; Gabillon, 2012; Clark-Goff \& Eslami, 2016) show that beliefs impact teaching practices as well as student learning.

Teachers' beliefs may include content-specific beliefs as well as teaching and learning (Fives et al., 2015). In the context of EFL, content-specific beliefs cover the beliefs on language components such as grammar, pronunciation, and vocabulary. Meanwhile, the prior beliefs of EFL student teachers entering language teacher education institution belong to underspecified beliefs about teaching and learning (Fives et al., 2015). Furthermore, understanding how people learn second/foreign language and its difficulties are of significant parts of beliefs about teaching and learning (Lucas et al., 2015). Lan and Lam (2020) break down teachers' beliefs into five specific core beliefs, namely English language, teaching, learning, teacher-student roles, and profession.

As EFL student teachers are still on their way to become EFL teachers that one day will be the agents of change (Lestariningsih et al., 2020), their beliefs will also influence their way of teaching and future students' learning. Due to their lack of experience in teaching, they might hold negative or unrealistic beliefs towards teaching and learning which might transform into their teaching. For example, a belief that grammar is the most important part of learning English could cause an EFL student teacher to focus more on grammar and pay less attention to such things as pronunciation or fluency in 
speaking skill. As a result, this might affect their students' learning negatively. That's why knowing the EFL student teachers' beliefs is significant to help them be better English teachers. As microteaching lesson study provides the environment for EFL student teachers to collaborate, engage, and reflect on their ideas, beliefs, and teaching experiences, their beliefs about language teaching and learning will likely change. This present study aims to investigate the effect of microteaching lesson study on the beliefs of the EFL student teachers.

\section{METHOD}

\section{Context for the study}

This study was conducted in the English Education Department of Universitas Muria Kudus (EED UMK). The EFL student teachers enrolled in the microteaching course applying microteaching lesson study. Those EFL student teachers were grouped heterogeneously based on their Grade Point Average (GPA). Thus, each group consisted of three student teachers with various level of English proficiency, i.e. low, intermediate, and high. Each group was involved in three cycles of lesson study, i.e. planning, implementing, and reflecting an English lesson for secondary schools. In planning step, EFL student teachers discussed and designed their research lesson plan collaboratively with their group. In implementing step, one of the EFL student teachers taught using the lesson plan while the others observed it. The last step of reflecting was when the EFL student teachers discussed and reflected on the result of the observation. This lead to the refinement of the lesson plan which would be used by the next EFL student teacher to teach. During the cycle of microteaching lesson study, the English student teachers instructional activities were video-recorded. Each EFL student teachers were given three times to practice teaching: two in front of their peers and one in front of real students, the students of secondary schools volunteering to be students in microteaching.

\section{Participants}

The participants involved in this study were the EFL student teachers enrolling in microteaching class $\mathrm{E}$. The $\mathrm{E}$ class was chosen because that was the only class applying microteaching lesson study among the other five classes. Moreover, the lecturer of class E has implemented microteaching lesson study for two years. There were twenty-two English student teachers participating in this study.

\section{Data collection}

The data were collected using a questionnaire adapted from the Beliefs about Language Learning Inventory (BALLI) developed by Horwitz (1988) that is widely used for research on the beliefs of second language teacher education. The adaptation was conducted by reducing the constructs that intersect with teacher efficacy concept. The questionnaire comprises of twenty questions having four criteria, namely the role of foreign language aptitude, difficulty of learning second/foreign language, the nature of language learning, and learning and communication strategies. 
Suryani, F.B., \& Rismiyanto (2021). The effect of microteaching lesson study on the beliefs of EFL student teachers. EduLite: Journal of English Education, Literature, and Culture, 6 (1), 1-9. http://dx.doi.org/10.30659/e.6.1.1-9

To answer it, the student teachers must choose from five options presented following a Likert scale. The options range from (1) strongly agree, (2) agree, (3) neutral, (4) disagree, and (5) strongly disagree. It was administered to EFL student teachers in the beginning and at the end of microteaching lesson study.

\section{Data analysis}

The quantitative data analysis was applied to the questionnaire. Descriptive and inferential statistics were used to determine if the EFL student teachers' beliefs changed during microteaching lesson study. A paired t-test was used to find the statistical significance of the beliefs of the EFL student teachers before microteaching lesson study and after microteaching lesson study.

\section{RESULTS AND DISCUSSION}

This study aims at investigating the effect of microteaching lesson study on the beliefs of the EFL student teachers. Table 1 shows the mean and standard deviation of EFL student teachers' beliefs before and after they experienced microteaching lesson study.

Table 1. The Mean and Standard Deviation

\begin{tabular}{lcc}
\hline \multicolumn{1}{c}{$\begin{array}{c}\text { EFL student teachers' } \\
\text { beliefs }\end{array}$} & Mean & Standard deviation \\
\hline $\begin{array}{l}\text { Before microteaching lesson } \\
\text { study }\end{array}$ & 2.49 & 0.24 \\
\hline $\begin{array}{l}\text { After microteaching lesson } \\
\text { study }\end{array}$ & 2.45 & 0.21 \\
\hline
\end{tabular}

The findings of this study indicate that the means of the beliefs of the EFL student teachers before microteaching lesson study and those after microteaching lesson study are more or less similar. This includes all criteria of beliefs, i.e. the role of foreign language aptitude, difficulty of learning second/foreign language, the nature of language learning, and learning and communication strategies. The mean value of the beliefs of the EFL student teachers before microteaching lesson study resulted from the data is 2.49 with the standard deviation 0.24. Meanwhile, the mean value of the beliefs of the EFL student teachers after they completed microteaching lesson study is 2.45 with the standard deviation 0.21 .

A paired sample t-test was employed to find out if there was significant difference between the beliefs of EFL student teachers before and after they participated in microteaching lesson study. The results were presented in Table 2. 
Table 2. Paired Sample t-test of the Beliefs of the EFL Student Teachers before and after Microteaching Lesson Study

\begin{tabular}{|c|c|c|c|c|c|c|c|c|c|}
\hline \multicolumn{10}{|c|}{ Paired Differences } \\
\hline & & \multirow[b]{2}{*}{ Mean } & \multirow{2}{*}{$\begin{array}{c}\text { Std. } \\
\text { Deviation }\end{array}$} & \multirow{2}{*}{$\begin{array}{l}\text { Std. } \\
\text { Error } \\
\text { Mean }\end{array}$} & \multicolumn{2}{|c|}{$\begin{array}{l}\text { 95\% Confidence } \\
\text { Interval of the } \\
\text { Difference }\end{array}$} & \multirow[b]{2}{*}{$\mathrm{t}$} & \multirow[b]{2}{*}{$\mathrm{df}$} & \multirow{2}{*}{$\begin{array}{l}\text { Sig. (2- } \\
\text { tailed) }\end{array}$} \\
\hline & & & & & Lower & Upper & & & \\
\hline $\begin{array}{l}\text { Pair } \\
1\end{array}$ & $\begin{array}{l}\text { Beliefs } \\
\text { before } \\
\text { MLS - } \\
\text { Beliefs } \\
\text { after } \\
\text { MLS }\end{array}$ & -.04091 & .22868 & .04875 & -.14230 & .06048 & -.839 & 21 & .411 \\
\hline
\end{tabular}

The result of the paired sample t-test shows that there is no statistically significant difference between the beliefs of the EFL student teachers before microteaching lesson study and that after microteaching lesson study since the $p$-value is 0.41 which is greater than the significance value $(p=0.41>$ 0.05). This means that microteaching lesson study does not influence the changes of the beliefs of the EFL student teachers.

The study of beliefs is crucial in second language teacher education as beliefs are an internal factor that influences teachers in their teaching. In this context, what the EFL student teachers believe about teaching and learning English will influence them in viewing their students, designing their lesson, and implementing the lesson plan in the classroom. As Buehl and Beck (2015) assert, beliefs are used by student teachers to filter and interpret information, to frame a specific problem or task, and to guide immediate action.

Jaimes (2013) states that beliefs are not static and can change over time. Some studies (Morine-Dershimer, 1993; Peacock, 2001; Matheoudakis, 2007; Grijalva \& Barajas, 2013; Borg et al., 2014) relate beliefs with particular courses and result in the changes of student teachers' beliefs after enrolling in those courses. This explains how beliefs can actually change due to some courses.

However, some other studies indicate that beliefs do not easily change even after student teachers experience particular course. A study by Yilmas and Cavas (2008) reported that teaching practice did not affect preservice elementary teachers' beliefs. Levin (2015) notes that some studies showed that teachers' beliefs were difficult to change. Those studies are consistent with this study that reveals that the beliefs of the EFL student teachers stay the same after they experienced microteaching lesson study.

This also confirms Prawat's (1992) premise that beliefs are resistant to change as the beliefs of the EFL student teachers in the current study do not show such significant changes due to microteaching lesson study. Skott (2015) states that "Beliefs are generally considered temporally and contextually stable reifications that are likely to change only as a result of substantial engagement in relevant social practices".

It can then be explained that the beliefs of the EFL student teachers did not significantly change since most of the EFL student teachers had their first teaching experience only during microteaching lesson study. Moreover, their teaching practices during microteaching lesson study were conducted three 
Suryani, F.B., \& Rismiyanto (2021). The effect of microteaching lesson study on the beliefs of EFL student teachers. EduLite: Journal of English Education, Literature, and Culture, 6 (1), 1-9. http://dx.doi.org/10.30659/e.6.1.1-9

times only due to the unfeasibility of the course time. As the EFL student teachers had not taught yet before they enrolled in microteaching lesson study, their teaching experiences were quite new. Even most of them taught for the first time in their first turn of teaching practice in microteaching lesson study.

Furthermore, the limited number of teaching practices underscore the lack of their engagement in teaching experiences as well. In fact, personal teaching experiences are the most contributing factor to teachers' beliefs (Prawat, 1992; Ellis, 2006) among other factors such as experiences as student and knowledge of school courses. Besides, beliefs change is a longterm endeavour (Skott, 2015). Chant et al.; Levin et al.; Luft and Roehrig (as cited in Levin, 2015) found that teachers' beliefs changed and developed as they gained more teaching experience. The unfeasibility of having more teaching practices during microteaching lesson study due to the course time seems to hinder the EFL student teachers to obtain more teaching experiences in which result in the hindrance of their change of beliefs.

The lack of number of teaching practices might contribute to the lack of more opportunities for EFL student teachers to participate in the discussion and reflection with their peers and teacher educators as well. Microteaching lesson study actually provides EFL student teachers with plenty of circumstances for collaboration through discussing and reflecting. It also gives learning opportunities beyond classroom settings for student teachers to get more learning values (Phuong, 2018). Borg et al. (2014) note that the courses that enable student teachers to reflect will likely influence their beliefs. In this case, the collaboration process in microteaching lesson study through discussing and reflecting does not influence the beliefs of the EFL student teachers. Beside the limited number of teaching practices that the EFL student teachers have, the same beliefs held by those student teachers might be the other influential factor. Thus, when the EFL student teachers participate in the discussion and reflection sessions during microteaching lesson study, they share the same beliefs and paradigms that finally do not impact the changes of their beliefs.

Accordingly, it is obvious that the EFL student teachers' beliefs are not affected by microteaching lesson study as they had just started their teaching practice for the first time and as they only had limited number of teaching practices. This implies that for EFL student teachers' beliefs to change, it takes time and more teaching practices in microteaching lesson study.

\section{CONCLUSION}

It takes time for beliefs to change. This occurs in the EFL student teachers during their microteaching lesson study as the present study confirms that microteaching lesson study does not have impact on the language learning beliefs of the EFL student teachers including the four criteria, i.e. the role of foreign language aptitude, difficulty of learning second/foreign language, the nature of language learning, and learning and communication strategies.

The findings of this study may result in new understanding of the static beliefs of the EFL student teachers when they experience microteaching lesson study. In fact, microteaching lesson study has provided student teachers with collaboration, reflection, and engangement that would likely change their 
Edulite journal of English Education, Literature, and Culture

Vol. 6, No. 1, February 2021, pp. 1-9

E-ISSN: 2528-4479, P-ISSN: 2477-5304

http://jurnal.unissula.ac.id/index.php/edulite

DOI: http://dx.doi.org/10.30659/e.6.1.1-9

beliefs. However, limited time of teaching practice in microteaching lesson study seems to be one of the most influential factors in hindering the changes of the student teachers' beliefs. This implies that a thorough attention should be given to EFL student teachers' beliefs as well as teaching practice duration. By knowing teachers' beliefs, teacher educators can help student teachers develop the knowledge, skills, and dispositions they need to be successful in today's classrooms (Levin, 2015). In addition, microteaching course especially microteaching lesson study should provide more time for the EFL student teachers to practice teaching during the course. The infeasibility of time due to the department rule might be resolved by adding more credit for microteaching course.

\section{ACKNOWLEDGEMENTS}

The research reported in this publication was supported by the English Education Department of Universitas Muria Kudus. Therefore our acknowledgements are truly addressed to this institution.

\section{REFERENCES}

Abad, J. V. (2013). Pedagogical factors that influence EFL teaching: Some considerations for teachers' professional development. Profile, 15 (1), 97-108. http://www.scielo.org.co/scielo.php?script=sci_arttext\&pid=S165707902013000100007\&lng=en\&nrm=iso\&tlng=en.

Altan, M. Z. (2012). Preservice EFL teachers' beliefs about foreign language learning. European Journal of Teacher Education, 35, 481-493. https://doi.org/10.1080/02619768.2011.643399.

Borg, S. (2011). The impact of inservice teacher education on language teachers' beliefs. System, 39(3), 370-380. https://doi.org/10.1016/j.system.2011.07.009.

Borg, S., \& Al-Busaidi, S. (2012). Learner autonomy: English language teachers' beliefs and practices. https://www.britishcouncil.org.

Borg, S., Birello, M., Civera, I., \& Zanatta, T. (2014). The impact of teacher education on pre-service English language teachers. https://www.britishcouncil.org.

Buehl, M. M., \& Beck, J. S. (2015). The relationship between teachers' beliefs and teachers' practices. In Helenrose Fives and Michelle Gregoire Gill (Eds.). International Handbook of Research on Teachers' Beliefs (pp. 66-84). Routledge.

Clark-Goff, K., \& Eslami, Z. (2016). Exploring change in preservice teachers' beliefs about English language learning and teaching. Iranian Journal of Language Teaching Research, 4(3), 21-36. https://doi.org/10.30466/IJLTR.2016.20352.

Ellis, E. M. (2006). Language learning experience as a contributor to ESOL teacher cognition. TESL-EJ, $10 \quad$ (1), 1-20. http://www.teslej.org/wordpress/issues/volume10/ej37/ej37a3/.

Fernandez, M. L. (2010). Investigating how and what prospective teachers learn through microteaching lesson study. Teaching and Teacher Education, 26(2), 351-362. https://doi.org/10.1016/j.tate.2009.09.012.

Fives, H., Lacatena, N., \& Gerard, L. (2015). Teachers' beliefs about teaching (and learning. In Helenrose Fives and Michelle Gregoire Gill (Eds.). International Handbook of Research on Teachers' Beliefs (pp. 48-65). Routledge. 
Suryani, F.B., \& Rismiyanto (2021). The effect of microteaching lesson study on the beliefs of EFL student teachers. EduLite: Journal of English Education, Literature, and Culture, 6 (1), 1-9. http://dx.doi.org/10.30659/e.6.1.1-9

Khader, F. R. (2012). Teachers' pedagogical beliefs and actual classroom practices in social studies instruction. American International Journal of Contemporary Research, 2(1), 73-92. http://www.aijcrnet.com/journal/index/87.

Gabillon, Z. (2013, November 14-16). A synopsis of L2 teacher belief research. [Paper presentation]. Belgrade International Conference on Education, Belgrade, Serbia.

Grijalva, S. D. C., \& Barajas, E. R. (2013). Pre-service teachers' beliefs about language teaching and learning: A longitudinal study. Profile, 15 (1), 81-95. http://www.scielo.org.co/scielo.php?script=sci_abstract\&.pid=S165707902013000100006\&lng=en\&nrm=iso\&tlng=en.

Horwitz, E. K. (1988). The beliefs about language learning of beginning university foreign language students. Modern Language Journal, 72, 283-294. https://doi.org/10.1111/j.1540-4781.1988.tb04190.x.

Jaimes, J. C. (2013). The role of English pre-service teachers' beliefs about teaching in teacher education program. Profile, 15(1), 195-206. http://www.scielo.org.co/scielo.php?script=sci_abstract\&pid=S1657$07902013000100012 \& \operatorname{lng}=$ en\&nrm=iso\&tlng=en.

Johnson, K. E. (2009). Second language teacher education: A sociocultural perspective. Routledge.

Lan, W., \& Lam, R. (2020). Exploring an EFL teacher's beliefs and practices in teaching topical debates in Mainland China. Iranian Journal of Language Teaching Research, 8(1), 25-44. https://doi.org/10.30466/IJLTR.2020.120806.

Lestariningsih, F. E., Madya, S., \& Nurkamto, J. (2020). Pedagogical problems encountered by teachers of English to computer science students in the Indonesian context. Edulite: Journal of English Education, Literature, and Culture, 5(1), 1-13. https://doi.org/10.30659/e.5.1.1-13.

Levin, B. B. (2015). The development of teacher's beliefs. In Helenrose Fives and Michelle Gregoire Gill (Eds.). International Handbook of Research on Teachers' Beliefs (pp. 48-65). Routledge.

Lucas, T, Villegas, A. M., \& Martin, A. D. (2015). Teachers' beliefs about English language learners. In Helenrose Fives and Michelle Gregoire Gill (Eds.). International Handbook of Research on Teachers' Beliefs (pp. 48-65). Routledge.

Matheoudakis, M. (2007). Tracking changes in preservice EFL teacher beliefs in Greece: A longitudinal study. Teaching and Teacher Education, 23, 1272-1288. https://doi.org/10.1016/j.tate.2006.06.001.

Morine-Dershimer, G. (1993). Tracing conceptual change in preservice teachers. Teaching and Teacher Education, 9(1), 15-26. https://doi.org/10.1016/0742051X(93)90012-6.

Ozmen, K. S. (2012). Exploring student teachers' beliefs about language learning and teaching: A longitudinal study. Current Issues in Education. 15(1), 1-16. https://cie.asu.edu/ojs/index.php/cieatasu/article/view/819.

Peacock, M. (2001). Preservice ESL teachers' beliefs about second language learning: A longitudinal study. System, 29, 177-195. https://doi.org/10.1016/S0346251X(01)00010-0.

Phuong, C. T. H. (2018). Language learning experience of two Vietnamese language adult learners. Edulite: Journal of English Education, Literature, and Culture, 3(2), 101-109. https://doi.org/10.30659/e.3.2.101-109. 
EduLite Journal of English Education, Literature, and Culture

Vol. 6, No. 1, February 2021, pp. 1-9

E-ISSN: 2528-4479, P-ISSN: 2477-5304

http://jurnal.unissula.ac.id/index.php/edulite

DOI: http://dx.doi.org/10.30659/e.6.1.1-9

Prawat, R. S. (1992). Teachers' beliefs about teaching and learning: A constructivist perspective. American Journal of Education, 100 (30), 354-395. https://doi.org/ $10.1086 / 444021$.

Skott, J. (2015). The promises, problems, and prospects of research on teachers' beliefs. In Helenrose Fives and Michelle Gregoire Gill (Eds.). International Handbook of Research on Teachers' Beliefs (pp 13-30). Routledge.

Yilmas, H., \& Cavas, P. H. (2008). The effect of the teaching practice on pre-service elementary teachers' science teaching efficacy and classroom management beliefs. Eurasia Journal of Mathematics, Science and Technology Education. 4 (1), 45-54. https://doi.org/10.12973/ejmste/75305.

Zhou, G., \& Xu, J. (2017). Microteaching lesson study: An approach to prepare teacher candidates to teach science through inquiry. International Journal of Education in Mathematics, Science and Technology (IJEMST), 5(3), 235-247. https://doi.org/10.18404/ijemst. 296039.

Conflict of Interest Statement: The authors declare that the research was conducted in the absence of any commercial or financial relationships that could be construed as a potential conflict of interest.

Copyright (c) 2021 Suryani and Rismiyanto. This is an open-access article distributed under the terms of the Creative Commons Attribution License (CC BY). The use, distribution or reproduction in other forums is permitted, provided the original author(s) and the copyright owner(s) are credited and that the original publication in this journal is cited, in accordance with accepted academic practice. No use, distribution or reproduction is permitted which does not comply with these terms. 